\title{
Sustainable Development and the Changes is the Modern Economic and Social Life
}

\author{
Stela Zhivkova, $\mathrm{PhD}$, \\ University for National and World Economy, Bulgaria,
}

\begin{abstract}
In the contemporary world, with its high technologies, constantly developing and improving production processes and globalization, the issue of sustainable development is present in the agenda of the whole world. Moreover, the international business in all its variety of forms and operations, is an integral part of the economic life of each country. It contributes to the increase of the gross domestic product of developed countries and for the economic progress of developing countries. In this context, what becomes important is not only achieving economic growth, but also the ways it is achieved. That's where the concept of sustainable development comes. The ideas of sustainable development, getting economic growth with care for the environment, reaching higher living standard while protecting the natural resources are extremely popular at the beginning of this century, when environmental disasters and economic crises caused by the scarcity of certain resources are a reality and are not limited to one specific country but affect the whole world. These problems inevitably lead to changes in the economic life, as it has to respond to the need of finding a new approach to achieve economic prosperity. Such changes in the economic and social life, for example, are the emergence of new economic sectors such as ecomanufacturing, bio-products, provision of environmental services, changes in some state policies such as initiating green procurement, green public-private partnership, green supply chains etc. This article is dedicated to revealing some of these changes which result from the current trend for sustainable economic development.
\end{abstract}

Keywords: sustainable development, international business, environment, green economy

\section{Introduction}

In the last decades of the twentieth century more and more important becomes the question about the continuously deminishing natural resources and the environment in all its components - air, soil, water, etc. The countries in Europe and the United States began its rapid economic development right after World War II and constantly develop and improve their production processes. At that time however the consequences of these actions on the environment and human health have been highly neglected.

Gradually, after achieving economic growth and building strong social rules and norms developed countries start focusing on issues like scarcity of the production resources and their exhaustibility, pollution of the surrounding nature, social inequality etc. Nowadays these problems stand as the main item on the agenda of each country and of the world as a whole. They are also embedded in the heart of one of the leading for the XXI century concepts, namely the achievement of growth and prosperity through sustainable development. Sustainable development is becoming a driving force of progress in modern societies and inevitably affects them. This article will address some of the changes seen in the economic life of the modern societies caused by the measures taken worldwide to achieve sustainability.

\section{The idea of sustainable development}

Nowadays the issue of sustainability is present everywhere around us. Whether we realize it or not, every action we do in our daily life - at work or at home - in one way or another is influenced by the ideas of sustainable development.

The literature contains a lot of information about what sustainable development is and what its features are. Some authors see it as a package of development programs that will help solving the problem of scarcity and lack of natural resources as well as the social equality (Bartelmus, 1994). Other authors accept it as a system of activities and mechanisms whose main 
purpose is to ensure optimal growth of the economy through the use of natural resources in the most efficient way and preserve them for future generations (Pearce, Barbier, Markandya, 1990). Still others present it as achieving a balance between social and environmental principles in a socially justified and environmentally sound economic development (Gechev, 2005). Moreover, the essence of sustainable development is expressed in the fact that "every generation must satisfy its needs complying with the needs of the future generations"1. The most widely used definition of sustainable development is the one given in the report titled "Our Future" prepared in 1987 by the World Commission on Environment and Development, led by Gro Brundtland, better known as the Brundtland Report. According to this report, sustainable development is the one that "satisfies the needs of the present without jeopardizing the ability of future generations to meet their needs."

The concept of sustainable development is built upon the three most important aspects in the life of every society - economic development, social equity and environmental protection ${ }^{2}$. In the context of sustainable development, they are known as the "pillars" of sustainable development.

The report formulates the following basic principles of sustainable development:

consideration of public priorities, not only with the needs of today but also the needs of the future generations;

even distribution of efforts to reasonably use of natural resources and restoration of ecological balance;

linking the economic to the environmental effectiveness;

equal environmental responsibility and cooperation between countries in solving global problems facing humanity.

This definition together with the basic principles of sustainable development leads to the conclusion that its main characteristic is to achieve society development and economic prosperity in harmony with nature. Based on this conclusion quite a lot of actions have been taken on global level to achieve this main goal. As a consequence of these actions some visible changes can be elaborated in the societies mostly of the developed countries but in the developing world as well. Some of these changes have been summaries in the next sections.

\section{Sustainable development and the economic activity}

In the last decades of the XXth century on international level quite some actions have been taken to protect the environment and to stimulate both the business and the people to be more environmentally and socially responsible. These processes are even more intense in our century. Thus, step by step, by the means mostly of legal requirements and prohibitions but also through a numerous number of initiatives the economies of the countries started to change. All economic participants, from the business and governments up to the ordinary people, started to see the sustainable development not only as a cost but also as an opportunity - business or social or financial but still an opportunity.

\subsection{New economic sectors}

The activities carried out within the sustainable development agenda, lead to changes in the economic life of the people. Economic operators for various reasons (whether under certain legal pressure, in search of new markets or competitive advantage) gradually change their way of working. This results in the emergence of new economic sectors and the production of new types of products.

\subsubsection{The sector of providing environmental services}

In the course of economic development and raising people's living standard, especially in developed countries, attention to environmental issues has become increasingly larger. The environmental care and the already existing public awareness in the people in industrialized countries, as well as the regulatory measures taken by the governments of each country,

\footnotetext{
1 Dacheva-Ilcheva N., Ilchev L. (2005) Ecology. Sustainable development. Environment. "Iztok-Zapad" publishing group, p. 7

2 http://www.worldbank.org/depweb/english/sd.html 
have forced the companies to develop and implement innovative environmental strategies and begin to work with thought of environmental protection (Martin-Tapia, Aragon-Correa, Senise-Barrio, 2008).

These trends give rise to a whole new sector in the economy of developed countries, namely the sector of providing services in the field of environment. This sector helps companies to measure and manage their environmental impact, to control their pollution and to treat their waste in an environmentally sound manner. New engineering companies emerge that create, market, install and apply environmentally friendly techniques and technologies. Many of the already established and successful companies also change and enrich their activities by offering nature-friendly equipment and technology. Numerous consulting firms appear that offer knowledge, experience and training to businesses on environmental protection. According to OECD data services sector in the field of environment in developed countries generates annual revenue of about $\$ 300$ billion?

Companies offering services in the field of environment expand their activities beyond the borders of their own countries and direct their attention to the developing world. The developing countries import from the developed world equipment that harms the nature in order to improve their own economic indicators. Rich countries on other hand export their polluting industries in the developing world to clean up their own environment. This imbalance opens new market niches and provides plenty of opportunities for the firms from the developed countries providing services in the field of environment, to enter and permanently stay in the economic life of developing countries by providing know-how; consulting services; importing new or used, environmentally friendly, production equipment; providing technical assistance to the private sector and public institutions etc. Thus the sustainable development ideas lead to development of a new economic sector namely the sector to provide services in the field of environment protection.

\subsubsection{Ecoproduction}

Another newly developed economic sector is the eco-production. Within the European Union, some Member States firms in the electrical and electronics industry in the late 90s of the last century have begun to look for ways to "clean up" their production. This leads to the emergence of the concepts of eco-design and eco-production. In general, this practice is associated with the production of products which are energy efficient, with long life and are easy to disassemble. Various research teams conducted studies aiming to find out the reasons for the measures taken by the companies to develop environmentally sound production. They identified two main groups of factors that stimulate firms to do eco-production external and internal. The most important external factors include customer requirements and legislative requirements. Many companies involved in the studies indicate that the adoption of legislative measures and the implementation of the 'producer responsibility' principle in terms of packaging and car industry for example, encouraged them to take measures to avoid more stringent requirements ${ }^{2}$. No matter what the driving force for applying eco-production was, the main result from these governmental actions was that the companies became more environmentally sensible and a new economic sector occurred.

\subsubsection{Bio-production}

Another modern economic niche resulting from the sustainable development ideas is the bio-production. In 1996, UNCTAD initiated the so-called "bio-trade". Bio-trade covers the collection, production, transformation and commercialization of goods and services derived from the local biodiversity, following the criteria for environment protection, social and economic sustainability. This initiative started as a support of the objectives of the Convention on Biological Diversity. During its implementation it has developed a unique portfolio of regional and national programs. Since 2003, part of the Bio-trade initiative also has become the Bio-trade Facilitation Program (BTFP), which is aimed at improving the sustainable management of biological resources, development of value-added products, processing and marketing ${ }^{3}$.

\footnotetext{
1 OECD (2000). "The Global Environmental Goods and Services Industry"

2 Gottberg A., Morris J., et al. (2006). Producers responsibility, waste minimization and the WEEE Directive: Case studies in eco-design from the European light sector. Science on the Total Environment 359

${ }^{3} \mathrm{http}: / / \mathrm{www}$.biotrade.org/index.asp
} 
Thus a new trend in the economy has been created fully functioning in accordance with the sustainable development principles.

\subsubsection{Environmental management systems (EMS)}

The overarching goal of all EMS is to improve the state of the environment by reducing the impact that products, services and manufacturing organizations have on it. Such standards are ISO 9001 for quality management, ISO 14001 for environmental management, the scheme for Environmental Management and Audit Scheme (EMAS), standards for product management, eco-labeling etc. The majority of these standards are voluntary. Some of them have even been developed by the initiative of companies and enterprises in developed countries and their goal is two-fold: first, to demonstrate the involvement of the business in environment protection, and second - these standards enable companies, especially transnational companies, easily to control their suppliers and sub-contractors, especially when working in markets or with partners from developing countries. The overall result of this is that firms in developing countries which want to enter the international market must comply and implement management and quality standards, the majority of which are related to environmental protection.

These standards have multiple benefits for organizations such as reduced costs, better image of the organization, comply with the requirements of consumers and environmental legislation, increase the attractiveness of the organization for investors and reduce the insurance burden.

They lead to development of steps for prevention from creating environmental problems, replacement of production equipment and facilities, improvement of production processes so as to achieve the same quality or even higher quality output, but consuming fewer resources. In other words, these standards change the way the companies work and help businesses both to optimize their operations and to embellish and be more competitive in both the local and international market. They also result in establishing another market niche as there are quite a lot of companies worldwide dealing with certification of the buinsess according to a certain EMS standard.

Changes resulting from the state policy in the field of sustainable development

When analyzing the changes that occur in society in the context of sustainable development, it is appropriate to draw attention to specific areas of economic life that change as a result of the intervention of the State.

\subsubsection{Green public procurement}

In recent years, increasing attention is paid to the environmental problems caused by the economic activity of the people. "Green products", "bio products", "green procurement" has appeared. In its effort to stay in the market and attract new and new customers, the business is looking for new solutions and strategies. In order to promote this trend the national and international regulatory authorities take appropriate actions such as announcing "green" procurements.

Green public procurements take place according to a procedure where the environmental aspects are part of the criteria for awarding a contract. Municipal, regional and/ or national authorities include requirements for environmental protection in all stages of the selection process. This encourages the use of environmentally friendly technologies. This approach also stimulates the search and selection of results and solutions that throughout the life cycle of the products have the least impact on nature.

This policy of the local and national authorities affects the functioning of the local and international business. In case of opening a public procurement that contains requirements the participants to demonstrate that they will fulfill their assignment according to certain environmental standards or that they have certain quality certificates, the companies are forced to operate in an environmentally sound manner. This approach has an impact also on the competition, particularly in the international business - international companies, especially large transnational companies have more opportunities to meet the requirements of such procurements and obtain a competitive advantage over local firms, especially in developing countries (Gunningham, Kagan, Thornton, 2003). This policy of the local and national authorities as well as the new competitive advantages that companies acquire influence not only the international business, but also the marketing strategies of companies, therefore they influence also the international marketing. 


\subsubsection{Green public-private partnership}

Public-private partnership (PPP) is a widespread form of cooperation. It represents the "interaction between the State and the private sector (national and international) in the implementation of initiatives solving socio-economic problems, creating public goods and promoting the sustainable development of the countries ${ }^{1 "}$. An important feature of the PPP is that the public sector buys services under certain conditions, which enables it to apply relevant incentives ${ }^{2}$. The environmental policy of each country aims to create appropriate conditions for a sustainable environment. By incorporating environmental elements in projects implemented on the basis of public-private partnership some "greening" of this partnership is achieved. It allows public institutions to take advantage of green technologies and materials that are too expensive and the authorities can not or should not get them as they would lead to increased costs of public goods and would be socially intolerable for the society. PPP projects show that investments in improving the environment can not only ensure the most advantageous funding through lower operational costs, but also health and social benefits such as better working conditions. Well designed public buildings for example will contribute to expanding the benefits for the population on the territory where they are located ${ }^{3}$.

\subsubsection{Eco taxes}

The care for environment is also seen in a field of the economic life, which is the sole responsibility of the State, namely fiscal policy. By definition, it aims to finance public sector and serve as a tool for income redistribution ${ }^{4}$. In the sustainable development context, however, there is a need the regulatory authorities at national and international level to implement this tool also for the environment as a means of "discouragement" of pollution (Ivanova, 2009).

Eco-fiscal policy is a key mechanism for sustainable development. European Environment Agency defines eco-taxes and eco-fees as an effective tool that can serve as an incentive for both consumers and producers, leading to some change in behavior in favor of using a more eco-efficient way of resources. They can also encourage innovation and structural change and enhance compliance with environmental legislation ${ }^{5}$.

Introduction or enhancement of ecotaxes does not significantly affect the competitiveness of the industry and has a great social impact and great benefit for the environment, but they will have meaningful results only if applied by all participants in the global market. Otherwise, they can lead to loss of valuable advantages (Getchev, 2006).

Important economic key to sustainable development is to ensure that prices and structure of incentives reflect the real costs and benefits of production and consumption ${ }^{6}$.

New trends on company level

Sustainable development has an impact on inter-company relations as well. Cooperation along the supply chain and the contracting process in the modern conditions also containe an element of nature care.

\subsubsection{Company mergers and aquisitions}

The ideas of sustainable development and the legal actions taken by the governments to embed this concept in the society and economy force the managers to take into account the environmental factor when planning production activities of their companies (López-Gamero, Molina-Azorín, Claver-Cortés, 2010). Environmental legislation can lead to improved competitiveness of companies and create competitive advantage (Testa, Iraldo, Frey, 2011).

\footnotetext{
1 Boeva B. (2008). International management. UI „Stopanstvo”. Sofia, p. 339.

2 Boeva B., Vasileva A. (2009). Public-private partnership. Economics, management, challenges. UI „Stopanstvo”. Sofia

${ }^{3}$ Stoychev I., Boeva B., Zhivkova S., et al (2012). Interim report from a scientific project "Global challenges in environment protection and international business changes. University for national and world economy. Sofia

${ }^{4}$ Ivanova V. (2009). For the need of an eco-fiscal policy in EU. Economic Alternatives Journal, issue 4

${ }^{5}$ European Environmental Agency (1996). Information bulletin № 18

${ }^{6} \mathrm{http}: / / w w w . u n e p . o r g / g e 02000 /$ english/index.htm
} 
More stringent rules, strict enforcement of environmental legislation and the need for adaptation to customers' requirements, directs some companies to make strategic alliances such as mergers and acquisitions. These forms of business relations are not a new strategy in the business world. What is new is that, due to the sustainability concept, the companies have to be more environmentaly and socially responsible. Nowadays they are used as a strategic approach to gain a competitive advantage by aquiring companies that meet certain environmental or social standards but do not have the capacity to stay on the market. Mergers and acquisitions can be used to identify competitors with existing skills and experience that could easily fit into the existing organization. This way the companies on one hand save resources to become complient with the governmental and societal demands and on other hand, by merging with or acquiring another company, they directly preserve their reputation, respond to the conteprorary needs and expectations and in addition gain more competitive advatages.

\subsubsection{Green supply chain}

Supply chain is associated with the production and economic activity both of the business sector and the public organizations. Supply chain is a cooperation of organizations and processes with the purpose to create products or services and bring them to the end users ${ }^{1}$. This is a union of customers and suppliers that purchase, process, distribute and sell products and services to one another and the final result is the creation of a specific end product ${ }^{2}$. The supply chain includes the whole range of processes and activities performed in the production and delivery, which transform the material and accompanying streams.

Focusing on sustainable development issues the importance of the environmental and social behavior of the suppliers of various elements in the supply chain increases. Contracting Authorities (manufacturers) in the entire supply chain define criteria for environmental protection that apply to its suppliers in the chains. Thus the supplies and end-products are converted into environmentally and socially friendly. With the spread of this phenomenon in the supply chain it 'gets greener'.

In a research dedicated to the methods for studying the relationship between environment and trade the authors even conclude that the supply chain is "embedded" in the environment as the economic and production activities are based on environmental resources because the nature provides all the important production inputs and energy production processes (Faße, Grote, Winter, 2009).

Management of the "green" supply chain is defined as "the integration of environmental concerns in the management of the supply chain, including product design, choice of materials, production process, delivering the final product to the customer and product management at the end of its use ${ }^{3}$.

\section{International trade and the sustainable development}

In the field of international trade back in the early 90 s some multilateral environmental agreements have been signed with the primary purpose to control some of the international exchange elements for environmental reasons. Such agreements are for example the Basel Convention on the Control of Transboundary Movements of hazardous waste, the Cartagena Protocol on Bio-safety part of the Convention on Biological Diversity etc.

Sustainable development and environmental protection are defined as main objectives also of the World Trade Organisation (WTO). Although the main task of the organization is to encourage international trade and open markets, even the preamble of the Agreement establishing the WTO includes provisions that allow its members to impose trade restrictions in order to protect their environment. The only condition is that those restrictions are applied according to the equality

\footnotetext{
1 Dimitrov P., Tolev M. (2010). Logistic system. Sofia, p. 26

2 USA National Research Council (2009). Surviving Supply Chain Integration: Strategies for Small Manufacturers. Committee on Supply Chain Integration, Commission on Engineering and Technical Systems

3 Stoychev I., Boeva B., Zhivkova S., et al (2012). Interim report from a scientific project "Global challenges in environment protection and international business changes. University for national and world economy. Sofia, p.67
} 
principle - to be valid for all countries ${ }^{1}$. Countries can use technical environmental standards and sanitary and phytosanitary measures and not to allow the import of goods that do not meet certain requirements.

This has a direct impact on economic operators in different countries and especially their competitiveness. For example, despite the measures for liberalizing trade between countries, especially between developed and developing countries, if there are requirements for environmental standards or standards for quality management for products imported in an economically developed country, the competitiveness of the importing companies coming from developing countries is strongly reduced compared to local producers of the same or similar products.

This is so also due to the fact that consumers in developed countries are much more sensitive to the environment, respectively are more demanding to the products they consume. Therefore they prefer to buy products bearing information that they have been produced without harming the environment or that the generated waste will be treated in an environmentally sound way. This forces the foreign companies on this market to apply the relevant environmental standards, but this also results in higher prices.

On the other hand, companies importing (both goods and services) in developing countries are enjoying great popularity and a good business climate in these countries. The reason is that in these countries even if there is some environmental legislation, it is not strictly enforced, as the aim is to stimulate economic growth at any cost. In addition, consumers in these countries do not have a well-developed sensitivity to environmentally-sound production and are inclined to consume goods imported from economically developed countries (betting on the image of the foreign companies). This enables foreign companies not to work with the quality and standards as in their own countries and are able to reduce their production costs and the prices of their goods (Wysokinska, Witkowska, 2005).

During the organized by the WTO negotiations in Doha in 2001, whose main purpose was to negotiate the liberalization of international trade by lowering trade barriers and to revise the trading rules, also attention was paid to the market opening for environmental goods and services and was stressed that the liberalization of trade in environmental goods and services would be beneficial for developing countries. They would be able to renew their obsolete production equipment at lower prices and would be able to receive services and know-how in preferential terms ${ }^{2}$.

During the preparation for the UN World Conference on Sustainable Development in 2012 "Rio + 20" quite a lot of analysis have been made on the benefits and risks arising from the transition to a more sustainable economy. One of these analysis concludes that the economy based on sustainable development can improve both the global trade and the trading conditions in each country. Drivers of this economy can be found in international trade through: the introduction of local rules and laws related to the protection of the environment; pressure from consumers prompted by a desire to protect the environment; development of national plans and programs; implementation of multiple measures and policies; conclusion of international agreements related to environmental protection and climate change ${ }^{3}$.

Thus these attempts on global level for making the world better place to live and for preserving it in a condition that would allow the future generations also to live in this world, inevitable change the way the economy functions. Even at first glance purely business operations such as international trade or mergers and acquisitions change in a way as to be in line with the modern trend and necessities.

\section{Discussion}

The analysis of the different views on sustainable development and the resulting changes somehow leads to the conclusion that the driving force behind these changes is mostly the activity of the State. This conclusion should not raise any bewilderment. It concerns one of the State's functions to take care of public goods, including the protection of the resources and the environment. The State implements this function by taking various measures. In the developed market economies, however, together with the State regulations there are quite a lot of activities initiated by the business itself. It is therefore

\footnotetext{
${ }^{1}$ WTO (2009). Background note. Trade and environment in the WTO, p. 1

2 WTO (2009). Doha Agenda - Eliminating trade barriers on environmental goods and services

3 UN (2011). RIO+20 Issues Briefs, Trade and Green Economy, March 2011
} 
appropriate to consider another approach to the changes in the economic life resulting from the initiative of the companies themselves.

The economic operators are not just idle participants in the economic processes, standing and waiting for the State or any other international authority to create legal requirements that they would follow. Quite the opposite - businesses, particularly in economically developed countries, have active participation and share the efforts of legislative bodies to protect the environment, although led in most cases by their own interests rather than selfless concern for nature protection. In this sense, the main motivation of the companies to undertake their own voluntary initiatives in the field of sustainable development is diverse. This is illustrated by the following quote:

"Some companies take the environment as an asset in terms of its physical resources, as well as a market opportunity. Other companies see it as an expense. There are several types of costs caused by:

Compliance - caused by the need to fulfill certain legal measures or societal requirements;

loss of activity, triggered by environmental pressure, which was not addressed earlier;

voluntary choice to make certain expenditures that are not required by the regulation. Companies would do this to retain the already established image, to expand market share or to prevent the introduction of stricter legislative measures in the future"1.

According to other authors the key drivers for large companies to pay attention to sustainable development and mostly to environmental protection are the economic losses from reduced sales due to consumer preferences, or obtaining benefits from adopting various environmental standards, or benefits from reducing production costs due to more environmentally friendly technologies. Stimulus might be also the increased costs to manage various natural resources, waste generation etc. (Nattrass, Altomare, 1999).

A survey among companies in Mexico and Canada outlines other three main reasons for the business to prefer to be sustainable and not wait for the adoption of regulations:

consumer demand for "green" products

reducing the costs for changes in production and

political motivation to avoid further regulation ${ }^{2}$.

The motivation for the operators readily to invest in environmental protection, clearly shows that the driving force of the business is not just to take care of the environment and to leave something for future generations. It is provoked by the need to comply with certain regulatory requirements or for purely economic reasons and corporate interests such as avoiding larger penalties and requirements when adopting any new regulations, to achieve greater competitiveness on the local or foreign market or just optimizing the manufacturing costs.

\section{Conclusion}

From the previous pages it is quite clear that the sustainable development has entered our life and inevitable leads to some changes. These changes could be summarised in short as follows:

thanks to the actions taken on international level to change the way the economies function nowadays new sectors in the economic life occurred such as the provision of services in the field of environmental protection, ecoproduction, bioproduction etc.;

\footnotetext{
1 Blair A., Hitchcock D. (2001). Business and Environment, Routledge, p. 3

2 Cloutier L., Thomassin P., Dagicour F., Rodríguez José-Carlos (2003). Local Environmental Protection and Trade: The Cases of Hog Production in Canada and Mexico
} 
different "voluntary" standards for quality management and environment protection have been developed;

a new tax in the fiscal policies of the countries has been introduced - eco-taxes;

governmental practives such as the public procurements and public-private partnership became "green";

new types of products called "green" products, services or goods appeared;

the supply chain within the production processes also got "green";

even the international trade, despite the constant aim for liberalization, approves barriers in order to protect the environment.

All these new trends in the economic activities worldwide undoubtedly show that the sustainable development is not another good idea that might be applied somewhere in the distant future. They illustrate that the long-years efforts dated back in the seventies of the last century are meaningfull and already give results. But they also indicate that there is still quite a lot of work to be done in order to achieve the main goal of the sustainable development - to preserve the resources and the nature for our children.

\section{References:}

[1] Bartelmus P. (1994). Environment, Growth, and Development: The Concepts and Strategies of Sustainability, Routledge

[2] Blair A., Hitchcock D. (2001). Business and Environment, Routledge

[3] Boeva B. (2008). International management. UI „Stopanstvo”. Sofia.

[4] Boeva B., Vasileva A. (2009). Public-private partnership. Economics, management, challenges. UI „Stopanstvo”. Sofia.

[5] Cloutier L., Thomassin P., Dagicour F., Rodríguez José-Carlos (2003). Local Environmental Protection and Trade: The Cases of Hog Production in Canada and Mexico

[6] Dacheva-Ilcheva N., Ilchev L. (2005) Ecology. Sustainable development. Environment. "Iztok-Zapad” publishing group

[7] Dimitrov P., Tolev M. (2010). Logistic system. Sofia

[8] European Environmental Agency (1996). Information bulletin № 18

[9] Faße A., Grote U., Winter E. (2009). Value Chain Analysis Methodologies in the Context of Environment and Trade Research, Discussion Paper No. 429, Gottfried Leibniz University of Hannover, Institute for Environmental Economics and World Trade

[10] Gechev R. (2006). Sustainable development and market economy. University for national and world economy. Sofia

[11] Gechev R. (2005). Sustainable development: economic aspects. University of Indianapolis Press

[12] Gottberg A., Morris J., et al. (2006). Producers responsibility, waste minimization and the WEEE Directive: Case studies in eco-design from the European light sector. Science on the Total Environment 359

[13] Gunningham N., Kagan R., Thornton D. (2003). Shades of green. Business, regulations and environment. Stanford University Press

[14] Ivanova V. (2009). For the need of an eco-fiscal policy in EU. Economic Alternatives Journal, issue 4

[15] López-Gamero M., Molina-Azorín J., Claver-Cortés E. (2010). The potential of environmental regulation to change managerial perception, environmental management, competitiveness and financial performance, Journal of Cleaner Production 18 (2010) 963-974 
[16] Martin-Tapia, Aragon-Correa, Senise-Barrio (2008). Being green and export intensity of SMEs: The moderating influence of perceived uncertainty, Ecological Economics 68 (2008) 56-67

[17] Nattrass B., Altomare M. (1999). The natural step for business: wealth, ecology and the evolutionary corporation, New Society Publishers

[18] OECD (2000) "The Global Environmental Goods and Services Industry"

[19] Pearce D. W., Barbier E. B., Markandya A (1990). Sustainable Development: Economics and Environment in the Third World. Edward Elgar Pub

[20] Stoychev I., Boeva B., Zhivkova S., et al (2012). Interim report from a scientific project "Global challenges in environment protection and international business changes. University for national and world economy. Sofia

[21] Testa F, Iraldo F., Frey M. (2011). The effect of environmental regulation confirms' competitive performance: The case of the building \& construction sector in some EU regions, Journal of Environmental Management 92 (2011) 2136-2144

[22] USA National Research Council (2009). Surviving Supply Chain Integration: Strategies for Small Manufacturers. Committee on Supply Chain Integration, Commission on Engineering and Technical Systems

[23] Wysokinska Z., Witkowska J. (2005). International Business and Environmental Issues - Some Empirical Evidence from Transition Economies, Polish Journal of Environmental Studies Vol. 14, No. 3, 269-279

[24] World Trade Organisation (2009). Background note. Trade and environment in the WTO

[25] http://www.worldbank.org/depweb/english/sd.html

[26] http://www.biotrade.org/index.asp

[27] http://www.unep.org/geo2000/english/index.htm 